116. 新高感度オルソフィルムの検討（主として脳血管 造影を目的として)

\title{
The study of new ortho high sensitive film - Main purpose of cerebral angiography -
}

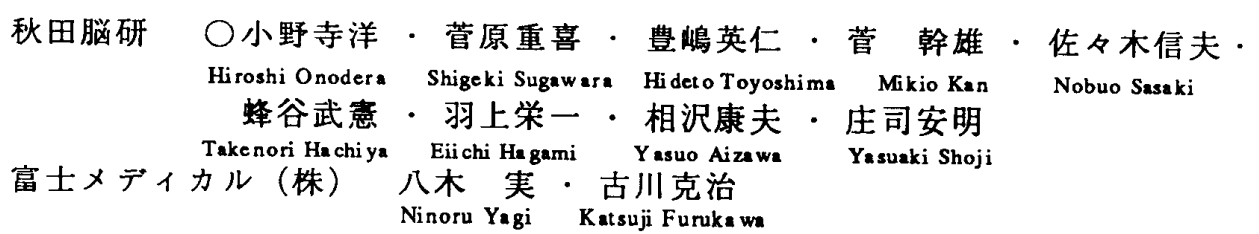

（目的）私共は、以前より脳血管立体拡大連続撮影での技術的検討を加えて来た。今回、富士 フィルムから血管造影での描出力向上を図るべく開発された、高感度高コントラストタイプオル ソフィルムSuper HR-HA と私共が従来から使用中の HR-H との諸特性評価及び脳血管造影での臨 床使用経験による性能評価を行なった。

(使用機器) X 線発生器 : PANDROS $1200 \mathrm{~A} 、 \mathrm{X}$ 線管球 : OPT I 110/12/50HSG、自現機：RU II（ $\mathrm{RD} 3 、 35^{\circ} \mathrm{C} 、 90$ 秒) 、X線フィルム:HR-H、Super HR-HA、增感紙 : New G-8、フィルムチェンジ ヤー：AOT-S、マイクロデンシトメータ：MPM-2 型、テストチャート：Funk No. 1、粒状性測定器 $: \mathrm{TD}-6500$

(方法) Fig. 1 に HR-H、Super HR-HA \& New G-8 による特性曲線を示す。測定条件は $80 \mathrm{KV} 0.1$ 秒、 水ファントーム $80 \mathrm{~mm}$ での距離法によった。

Fig. 2 に同様組合せによる鲜鋭度測定結果を示す。 测定条件は $80 \mathrm{KV} 0.1$ 秒、Focus $0.2 \times 0.2 \mathrm{~mm}$ 、 測定アパーチュア $20 \times 250 \mu$ で AOT 静止状態。 Fig. 3 に同じく、粒状性測定結果を示す。測定 アパーチュア $300 \times 300 \mu$ 、TD-6500 にて RMS 值 を求めた。

(䎯果)（1）高感度高コントラストタイプオルン フィルム Super HR-HA は、従来の HR-HA に比較 し感度は $10 \%$ 、鲜鋭度は 5 \%、可は 0.2 それぞ れ上昇している。（2）粒状性は高濃度部にかけ悪 化をみたが臨床上支障を来すことはなかった。

（3）私共の臨床使用上、特に高コントラスト化と 色調のブルー化により、アンギオ適正である階調 化が図られ臨床診断上有用との評価を得た。

Fig.1 特性曲線

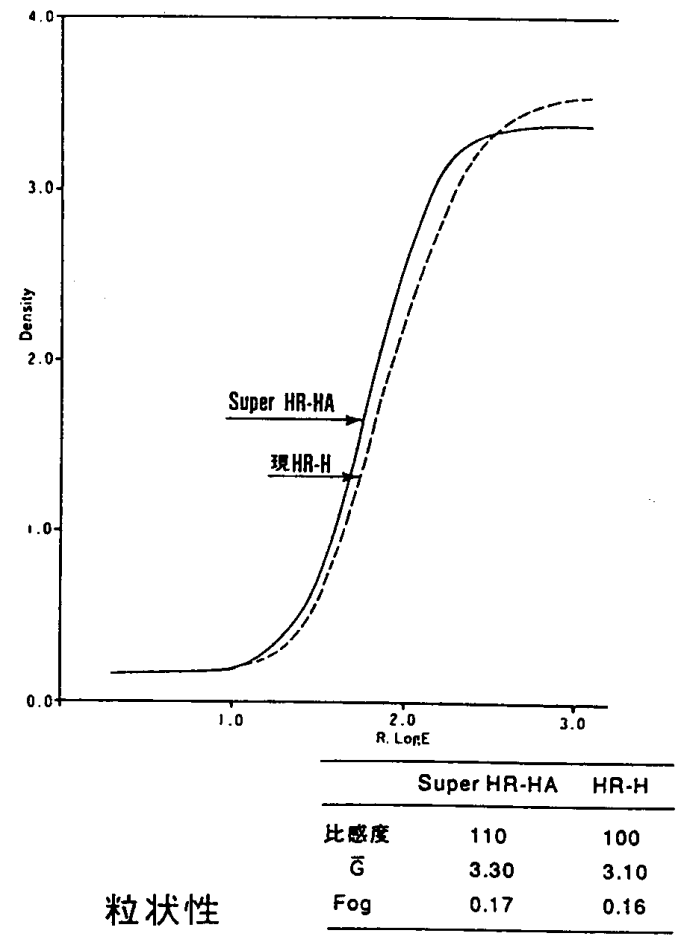

Fig. 2 鮮鋭度

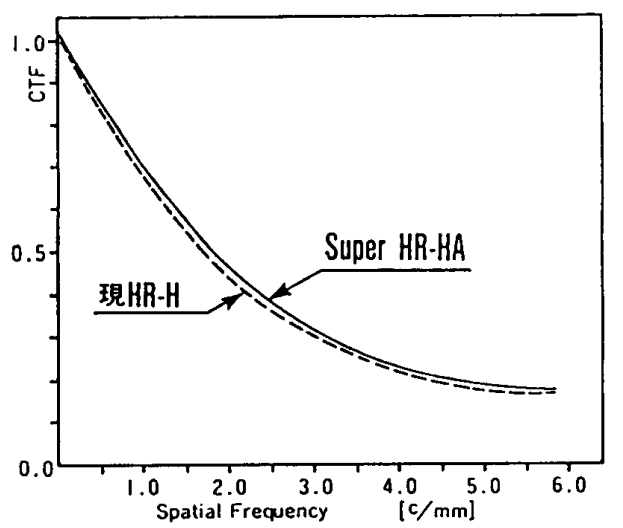

Fig.3 粒状性

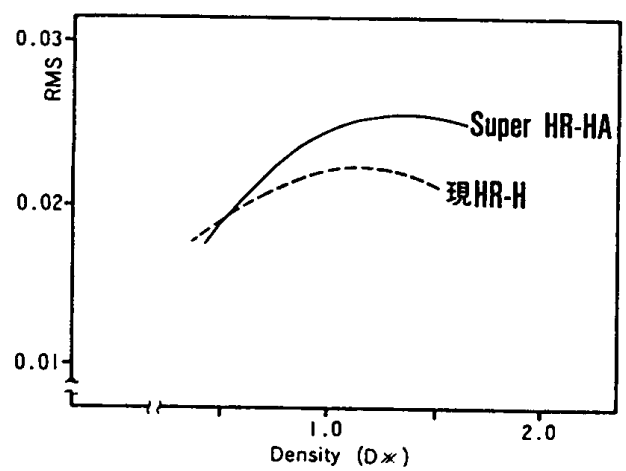

